\title{
İletişim Aracı Olan Yüzün İmge Olarak Seramik Yüzeylerde Kullanımı
}

\author{
The Use of Face as a Communication Tool on Ceramic Surfaces as an Image
}

\section{Yasemin Tanriverdi}

Dr., Mimar Sinan Güzel Sanatlar Üniversitesi Güzel Sanatlar Fakültesi Seramik ve Cam Tasarımı Bölümü

email: yasem.t5@gmail.com (DORCID ID: https://orcid.org/0000-0002-6869-4454

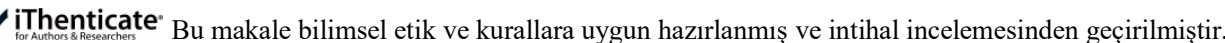

Atıf (APA 6)/To cite this article

Tanrıverdi, Y. (2020). İletişim aracı olan yüzün imge olarak seramik yüzeylerde kullanımı. Atatürk Üniversitesi Güzel Sanatlar Enstitüsü Dergisi, 26(44), 150-160. doi: https://doi.org/10.35247/ataunigsed.674526

Makale Gönderim Tarihi/Received: 14/01/2020

Makale Kabul Tarihi/Accepted: 11/03/2020

Makale Yayın Tarihi/Published: 19/03/2020

Review Article / Derleme Makalesi

$\ddot{O} z$

Sanat insanoğlunun önemli ifade biçimlerinden biri olarak, kültürle kurduğumuz bağda geçmiș ile şimdi arasında bir köprü görevindedir. Insanın yeteneklerinden biri iletişimdir ve yüz ifadeleri en az sözcükler kadar önemlidir. Çoğu zaman duygularımızı yüz ifademiz ile aktarırız. Yüzümüz ile kimliğimiz arasında bir bağ vardır. Kimlik, bir topluluğun veya kişinin kendine has vasfi, yeri ve kıymeti, yani insana özgü olan değerlerin göstergesidir; insanın kişiliğine dair bütün özelliklerinin toplamıdır. Kolektif kimlikler içerisinde, kişi kendi bireysel kimliğini olușturur. $\mathrm{Bu}$ kimlikler birbiriyle uyum içindedir; bir arada biçimlenip gelişirler. Yüz ifadeleri yaşam içerisinde edindiğimiz bu kimlikleri ve durumlar karsısındaki duruşumuzu ve duygularımızı tam olarak yansıtmaktadır.

$\mathrm{Bu}$ çalı̧̧mada, tarihsel süreç içerisinde, yüz imgesinin seramik objeler üzerinde kullanımı ve bu imgeyi kullanan sanatçılar incelenmiştir. Farklı ifadelerin aktarımında etkili olan yüz, imge olarak birçok sanatçının eserlerine kaynak olmuștur. İfadenin iki farklı aracı olan sanat ve yüz, sanatçıların eserlerinde bir araya gelmiştir. Sanatçıların yüz imgesini kimi zaman duygu aktarımında, kimi zaman da farklı kimliklerin yansıması şeklinde eserlerinde yer verdiği görülmüştür.

Anahtar kelimeler: Seramik, Kimlik, Yüz, Kültür

\begin{abstract}
As one of the most important forms of expression for human beings, art has an important role between past and present in our cultural bonds. One of the most important talents of mankind is communication, and facial expressions are as valuable as words for this communication. Most of the time, we convey our feelings through our facial expressions. There is a connection between our identity and our face. Identity is an indication of a community or person's unique qualification, state and value, that is, values that are unique to man; it is the sum of all the features of the personality. Within collective identities, a person creates his/her own individual identity. These identities are in harmony with each other; they form and develop together. Facial expressions fully reflect these identities that we have acquired in life and our stance and feelings towards situations.
\end{abstract}

In this study, artists who used face as an image in their works are examined and the use of face image on ceramic objects in the historical process is analyzed. The face, which is effective in the transfer of different expressions, has been the source of the works of many artists as images. Two different means of expression; art, and face, come together in the works of artists. Artists sometimes apply the face as an image in their works for emotion transfer through artworks, and sometimes use it in order to reflect different identities.

Keywords: Ceramic, Identity, Face, Culture

\section{Giriş}

Sosyal hayatımızda duyguların aktarımında, iletişim aracı olarak sözsüz ifadenin önemi uzun zamandır bilinmektedir. Kişiler arası iletişimde önemli bir rol oynayan yüz ifadeleri, insanların duygu, düşünce ve ruhsal durumları ile ilgili önemli bilgiler içermektedir (Bayrakdar, Akgün ve Yücedağ, 2016, s. 383-398). Psikolojide uzun yıllar yüz ifadelerinin kültüre özgü olduğu bakış açısı kabul edilirken, son yıllarda yüz ifadelerinin doğuştan ve evrensel olduğu kanısına varılmıştır (Metin ve Doğan, 2019, s. 1-26). İnsanoğlu varoluşunun gereği yaşam içerisinde farklı kimlikler takınır ve bulunduğu ortam içerisinde bu kimlikleri sürdürmek durumundadır. Yunanca'da 'Kişi', 'person' sözcüğünden türemiştir. Burada kullanılan 'person' sözcüğü, tiyatro oyunlarında kullanılan maske anlamını taşımaktadır (Ergil, 1994, s. 3). Bu aynı zamanda kişi olarak doğru zamanda doğru maskeleri takmak anlamına gelmektedir. Toplum içinde uyulması gereken belli normlar vardır, bunlar toplumdan topluma değişiklik gösterebilir. Toplumların önceden belirlemiş olduğu roller sayesinde insanlar bulundukları ortamlara uygun davranışlar sergileyerek onay kazanabilmektedirler. Aile içerisinde anne, baba, çocuk veya eş kimlikleri taşırken iş hayatında patron, işçi, elektrikçi gibi örneklerini arttırabileceğimiz farklı kimlikler taşınmaktadır. Bu kimliklerle birlikte duygu durumlarımız farklılık gösterebilir. İş yerinde çok sinirli iken evde çok sakin bir ruh hali içinde ola bilinmektedir. İnsan kimliğini ve içinde bulunduğu değerler sistemini bağdaşık bir yapı veya tek durumlu bir yapılanma olarak düşünmemek lazımdır (Şimşek, 2002, s. 29-39). Öncelikle insan bulunduğu anda, kendi geçmişi ve geleceği içinde bir bütün olarak düşünülmelidir. Duyguların anlaşıldığı en etkili iletişim aracı yüzdür. Kullanılan herhangi bir yüz ifadesi, kişinin duygu durumunu, davranışını, kişiliğini ve içerisinde bulunduğu psikolojik halini yansıtarak bir iletişim arac1 görevi görür (Güneş ve Polat, 2009, s. 7-14). 
Yaşam içerisinde takılan farklı maskeler, farklı yüz ifadeleri gerçeğin birer yansımalarıdır.

\section{Yöntem}

Araştırmada betimleyici bir yöntem kullanarak nitel bir araştırma yapılmışıı. Konu kapsamında literatür taraması yapılarak veri toplanma yoluna gidilmiştir. Toplanan veriler ışı̆̆ında seramik sanatında kullanılan yüz imgesi ve eserlerinde bu imgeyi kullanan sanatçılara yer verilmiş̧ir. Literatür taraması esnasında yeterli veriye ulaşılamayan sanatçılarla görüşme yapılarak eserleri hakkında bilgi alınmıştır.

\section{Bulgular ve yorum}

\subsection{Tarihte yüz formunun seramik yüzeylerde kullanımı}

"Derin olan her şey maske sever; en derin şeylerse imge ve meselden nefret eder."

\section{Friedrich Nietzsche (Sayın, 1999, s. 9)}

Antik çağlardan bu yana yüz, imgesel olarak seramik yüzeylerde kullanılmaya başlanmış ve halen de kullanılmaya devam etmektedir. Seramik kafa kaseleri veya maskeleri, ölen kişilerin geri dönmesi düşüncesi ile kafatasları üzerine yapılmıştır. Yüz figürü, yaklaşık 8.500 ile 9.300 yıl önce, Jericho'da insan kafataslarının alçıyla şekillendirilip süslenmesi ile görülmeye başlanmıştır. Bu kafataslarının, sanatsal ve özenli bir biçimde şekillendirilmesi, onların atalarına hürmet ve bir tür ölüm sonrası yaşam umudunun önerisi olduğu düşünülmektedir (Hirst, 2017, s. 1-4). Jericho sıvalı kafatasları, M.Ö. 7000'de kilin, hayvan ve insan figürlerinin, erken çömlek formları da eklenerek yerleşik topluluklara geçildiği zamana kadar izlerine rastlanmaktadır.

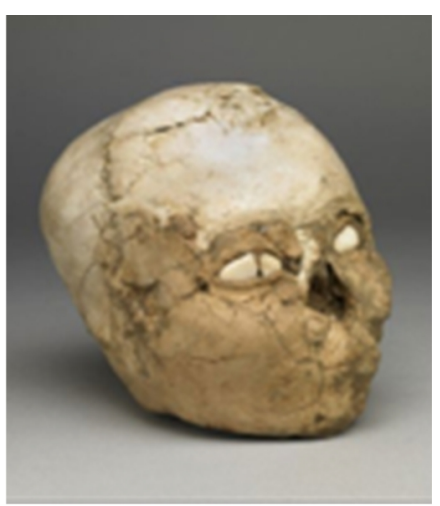

Görsel 1. Jericho Kafatası, 8500-9.300 yaşında, British Museum

Görsel 2'de yer alan maske M.Ö. 1. yüzyll, İskenderiye, Mısır'da üretilmiştir ve Mısır'ın erken Roma döneminden Kleopatra, Marcus Anthonius ve Julius Caesar zamanına aittir. Çok güçlü, etkileyici bir yüze sahip harika bir terakota maskesidir. Tasvir edilen adamın büyük bir burnu, çatık kaşlarının altında oldukça delici gözleri ve belirgin dudakları bulunmaktadır. Kıvırcık saçlarının kalıntıları alnında görülebilmektedir.

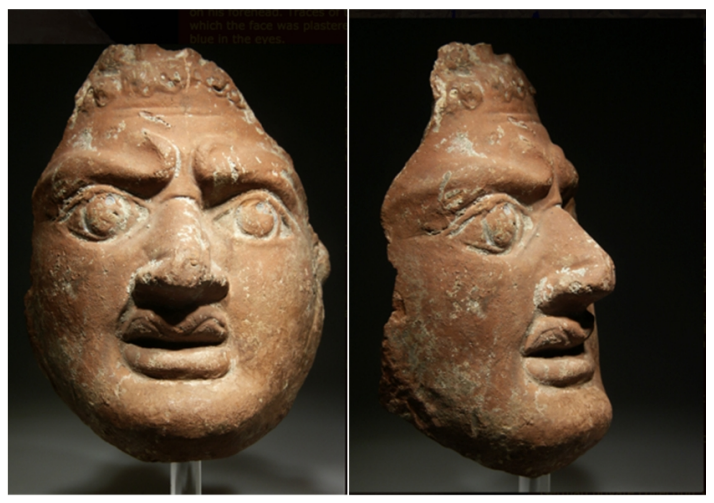

Görsel 2. Roma-Mısır Çömlekçilik Maskesi, M.Ö. 1

Erken dönemlerden beri, ölüm ve cenaze törenleri, bütün toplumlar için önemli ve kutsal olmuştur (Civelek, 2007, s. 71-80). Bu geleneklerin çoğu günümüze kadar devam etmiştir bazıları ise yok olup gitmiştir. Ölümün gizli yüzü, insanlarda başka bir hayat olabileceği inancının oluşmasına neden olmuştur ve böylece ölümden sonra gelecek hayatlar için ritüeller yapılmıştır. Sanatla iç içe olan Romalılar da imgenin egemenliğinde hayatlarını sürdürmüşlerdir. Ölümden sonra gelen yaşama inanan Romalılar, cesetlerin yüzlerinin maskelerini almalarının kendinden sonrakileri ve ülkelerini koruyacaklarını düşünmekteydiler. Atalarının evlerine girince yabancı 
sanatçıların imgelerinin görülmeyeceği inancı vardı (Sayın, 2003, s.36). Kapıların üstlerine soylu atalarının cenazelerine eşlik eden maskeler doldurulurdu. Ölen kişiyle birlikte ailenin bütün fertlerinin maskeleri sergilenmekteydi. Böylelikle ailenin soy ağacı çıkmış ve bu yüzler bir imgeye dönüşmüştür.

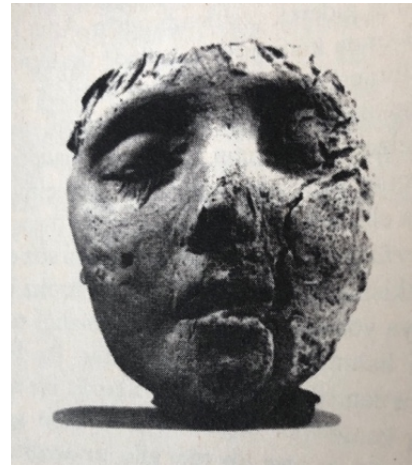

Görsel 3. Roma Cumhuriyetinden kalma çocuk maskesi, Vatikan Müzes

Yine Oglakhty Dağı yakınlarındaki mezarlıktan çıkan, M. Ö. 3.-4. Yüzyıllara ait erkek ve kadın maskeleri, ölülerin yüzleri üzerinde etkili bir şekilde ince kaplamalar olarak üretilmiştir. Yüze bir doğal alçı tabakası yayılarak yapılmıştır. Daha sonra boyanmış son bir kat saf alçı ile biten başka katmanlar ilave edilmiştir. Bu teknik nedeniyle, maskeler ölenlerin yüz özelliklerini oldukça doğru bir şekilde iletebilmektedir. Erkek ve kadın maskeleri farklı şekilde renklendirilmiştir. Kadınlar kırmızı spiraller ve parşömenlerle beyaz ile boyanırken, erkekler kırmızı, üzerlerinde siyah çizgiler şeklinde desenlendirilmiştir. Geleneksel toplumlarda sıkça görülen bir uygulama iken, günümüzde nadir rastlanan bir ritüel olmuştur.

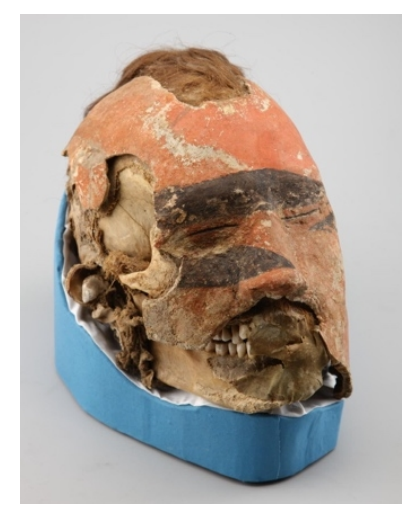

Görsel 4. Tashtyk Kültür, bir adamın kafasına yapılmış ölüm maskesi, M.Ö. 3.-4

Moche uygarlığına ait seramik eserler ise, arkeolojik kazılarda en iyi korunmuş eserler olarak tanımlanmaktadır (Donnan 1979, s. 97). Moche kapları, genellikle iki kategoriye ayrilan farklı seramik kap tipleri olarak bilinmektedir; modellenen ve astarlanmış kaplar. Her iki tipin de farklı formları vardır (Donnan 1979, s. 55). Moche uygarlığına ait kafa kaplarının kendi toplumları üzerinde önemli bir rol oynadığı ortaya çıkmıştır (Donnan 1979, s. 21-24). Bu kaplar genellikle törensel faaliyetlerde kullanılmıştır. Kafa kaplara yüklenen mesaj, değerleri hakkında fikir vermektedir (Donnan 1979, s. 55). Terakota seramikler uygarlığın toplum üzerinde etki sağlaması için kullanılmıştır.

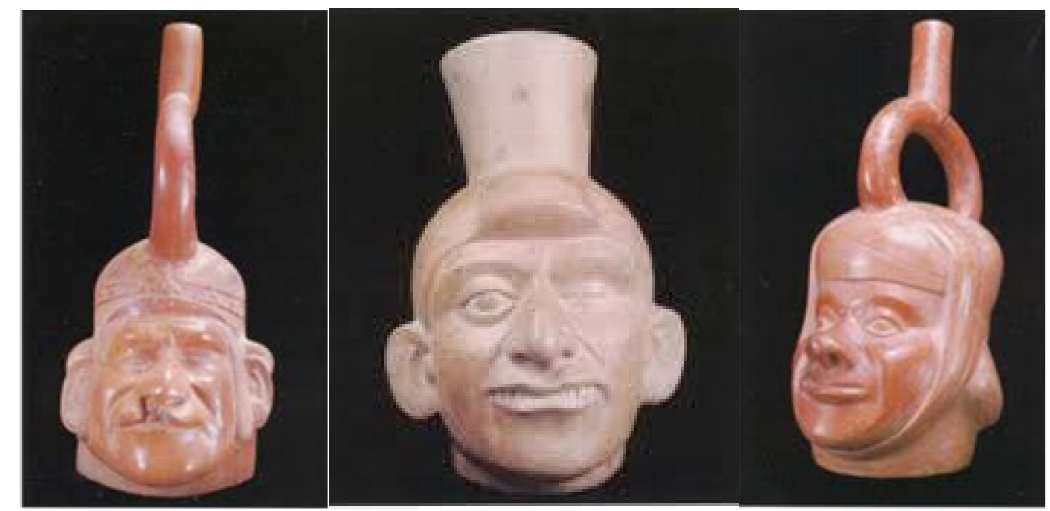

Görsel 5. Antik Peru Moche uygarlığından bir seramik kaplar, M.S. 200 ile 700 
Meksika, Yucatan’a ait bu eski Maya seramik form Geç Klasik Dönem’e yani yaklaşık M.Ö. 600-900 kadar uzanmaktadır. Görsel 5'te yer alan seramik kabın sağ yanaklarında kesik bir desen ve solunda ise aplike noktalardan oluşan tasarımlar bulunmaktadır. Bu yüz formunun, sağ yanağındaki kesik tasarım, konuşma, duman veya belki de bir dövme anlamına gelebilir. Sömürge döneminden kalma bir İspanyol olan 'Relacion de Motul', Maya erkeklerinin yirmi beş yaşından itibaren kollarında, bacaklarında ve yüzünde dövmeler olduğunu söylemektedir.

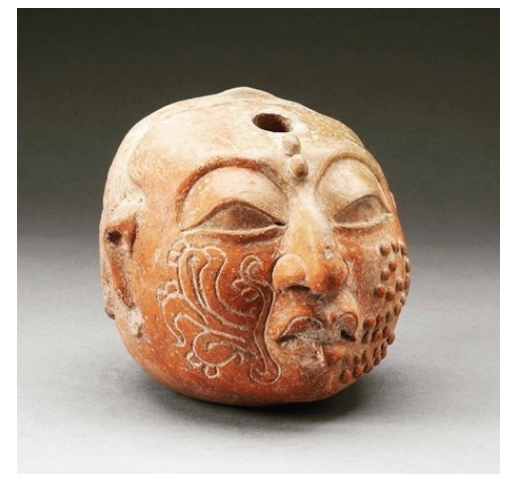

Görsel 6. Kafa Şeklinde Ritüel Seramik kap, M.S. 600-900, Geç Klasik Maya Yucatan, Meksika

M. S. 1200 ile 1500 yılları arasında yapılmış olan seramik kafa şeklinde kaplar çoğunlukla kuzeydoğu Arkansas ve güneydoğu Missouri'de bulunmuşlardır. Missipi’ye ait insan kafası kapları, ülkede bulunan nadir seramik kaplar arasındadır. Bu seramik kapların sadece 140 adeti kurtarılarak günümüze ulaşabilmiştir. Bulunan seramik kapların bir kısmı da parçalanmış haldedir. Ne yazık ki çoğu erken antikacılar tarafından yağmalanmış veya kazılmıştır, bu yüzden arkeolojik bağlamları bilinmemektedir (Rowe, 2015, s. 18). Ölülerin bir temsili, bir ölüm maskesi olduğu düşünülmektedir. Genellikle renklendirilmişlerdir ve dövme veya kazıma şeklinde çizgiler vardır. Kafa şeklinde kaplar renklendirilirken kırmızı ve beyaz astarlar kullanılmıştır. Birçok başlığın kulaklarında delikler vardır ve burun delikleri tasvir edilmiştir. Bu kaplar, tanrıya bir teklif olarak gömülmeden önce muhtemelen tüyler veya diğer malzemelerle süslenmişlerdir.

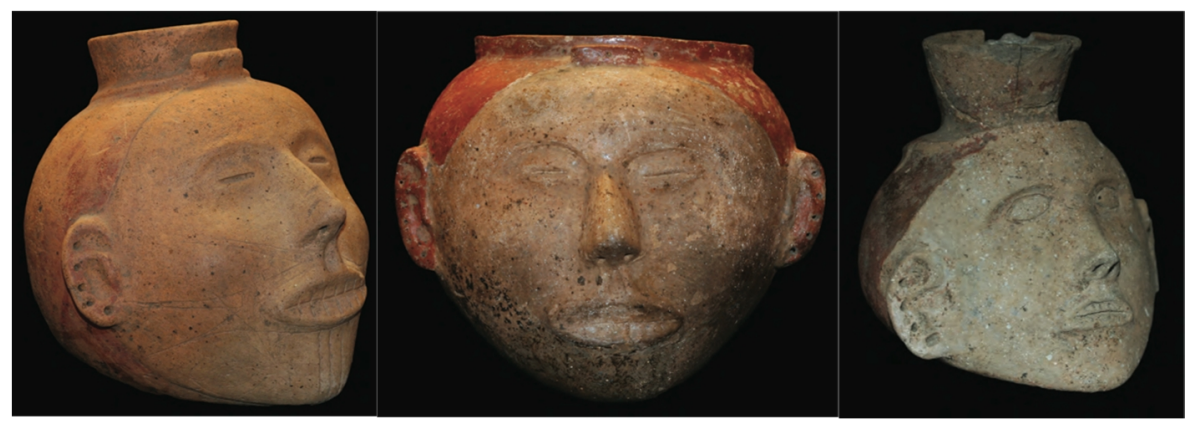

Görsel 7. Missipi kafa kapları, M. S. 1200 - 1500, Native American History Müzesi

Bu kafa kaplarının bazılarında yüz tasarımları kazıma yoluyla dekorlanmıştır. Missipi kafa grubunda yaklaşık 19 tarz bulunmaktadır. Süslü yüzleri olan kaplar, dövmelerine göre iki ana gruba ayrılabilir; kuşlu olanlar ve güneşli olanlar. Bu basitleştirilmiş motifler göksel güçleri sembol etmektedir. İlk grup, bir ya da her iki tapınak üzerine yerleştirilmiş ve kanatları göz yuvalarını çevreleyen kuş tasarımlarına sahiptir. İkincisinin alnında, paralel çizgilerin kardinal yönler boyunca dallandığ 1 dairesel bir motif yer almaktadır. Her iki grupta da burun köprüsü ve çene üzerinde çizgiler olabilir, yanaklarda ve ağız çevresinde ek tasarımlar değişebilmektedir.
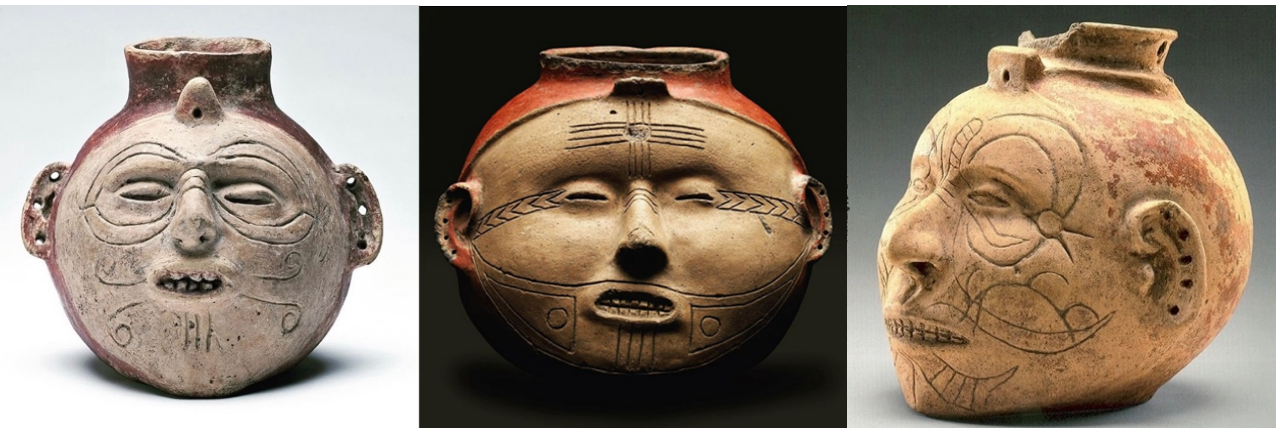

Görsel 8. Missipi kafa kapları, M. S. 1200 - 1500, Native American History Müzesi 


\subsection{Eserlerinde yüz imgesi kullanan sanatçılar}

Pablo Picasso, 1946 yılında seramik çalışmalarına başlamış, 1973'te sanatçı ölümüne kadar devam etmiştir. 1946 yılında Güney Fransa'da bulunan Vallauris şehrindeki bir seramik festivalini ziyaret eden sanatçı, burada Madoura çömlek atölyesini bulur ve atölyenin sahipleri olan Georges ve Suzanne Ramié ile uzun sürecek olan bir dostluk ve iş ilişkisi içerisine girer (İnan, 2018, s. 13). Sanatçı, atölyede bulunan işlerden ve bizzat malzeme olarak çamurdan oldukça etkilenmiştir. Tabak gibi işlevsel formlarla çalışmaya başlayan sanatçı teknik becerisini geliştirdikçe testi, vazo gibi formlar üretmeye başlamıştır. Picasso eğlenceli tavrıyla birlikte, Yunan mitolojisinden figürler ve çeşitli insan yüzleri gibi imgeleri seramik yüzeylere aktarmıştır.

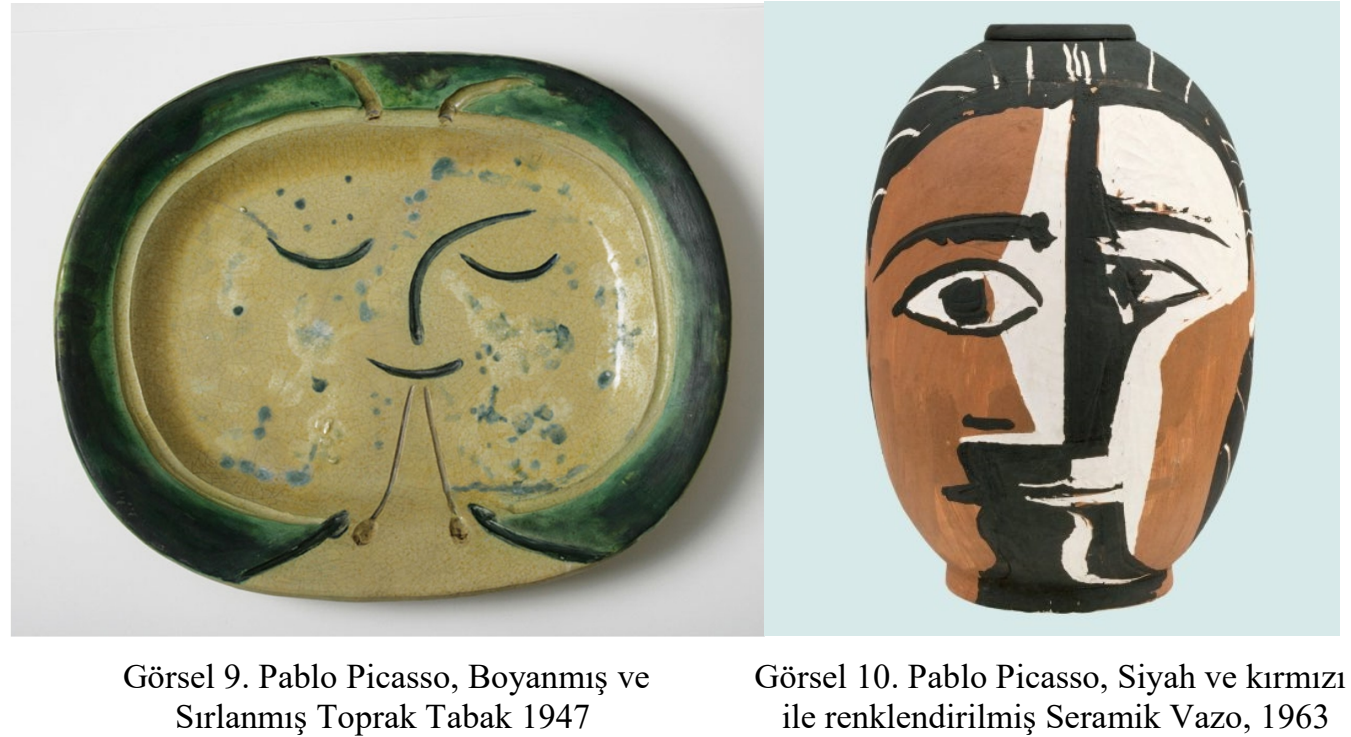

Bedri Rahmi Eyüboğlu'nun gençlik yıllarından beri süregelen heykel gibi seramiğe olan ilgisi onu bu alanda araştırmaya itmiştir. Sanatçı 1940’lı yıllarda yazları yaşadığı Beylerbeyi’nde Göksu deresi kıyısında rahmetli çömlekçi Hasan'dan edindiği çamur ile evinde fincanlar, tabaklar yapmıştır; fakat sanatçının seramiğe olan bu dürtüsünün en güzel örnekleri Sadi Diren ile yaptığı çalışmalarda gün yüzüne çıkmıştır. Farklı disiplinlerde çalışmalar sergilemiş olan Eyüboğlu, seramik eserlerinde yüz imgesini kullanmıştır.

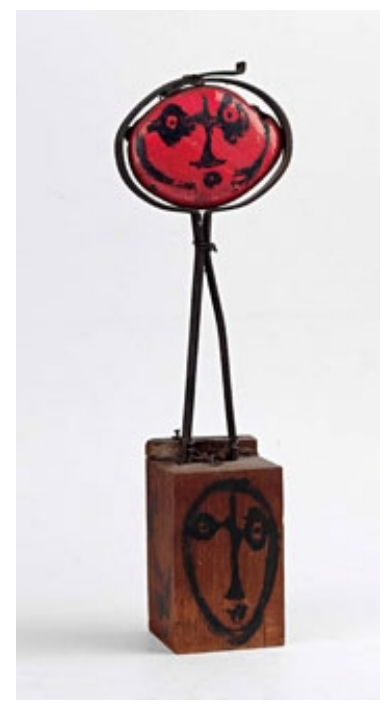

Görsel 11. Bedrim Rahmi Eyüboğlu Seramik Heykel

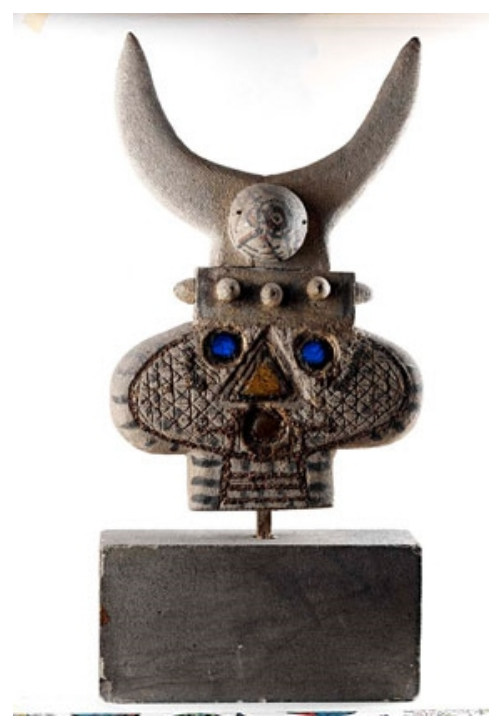

Görsel 12. Bedrim Rahmi Eyüboğlu Seramik Heykel

Eren Eyüboğlu da tıpkı Bedri Rahmi gibi Beylerbeyi'nde geçen yaz aylarında seramik çalışmalarına başlamıştır. Eyüboğlu en önemli seramik eserlerini rahmetli Atilla Galatalı ile üretmiştir. Sanatçı eserlerinde folklorik hususları plastik değerlerle birleştirmiş, özellikle süslemecilikten uzak durmuştur. Portre ve figürleri eserlerinde kullanan sanatçının 1930'lu yıllarda yaptığı çalışmalarda geleneksel süslemelere yer verdiği görülmektedir. 


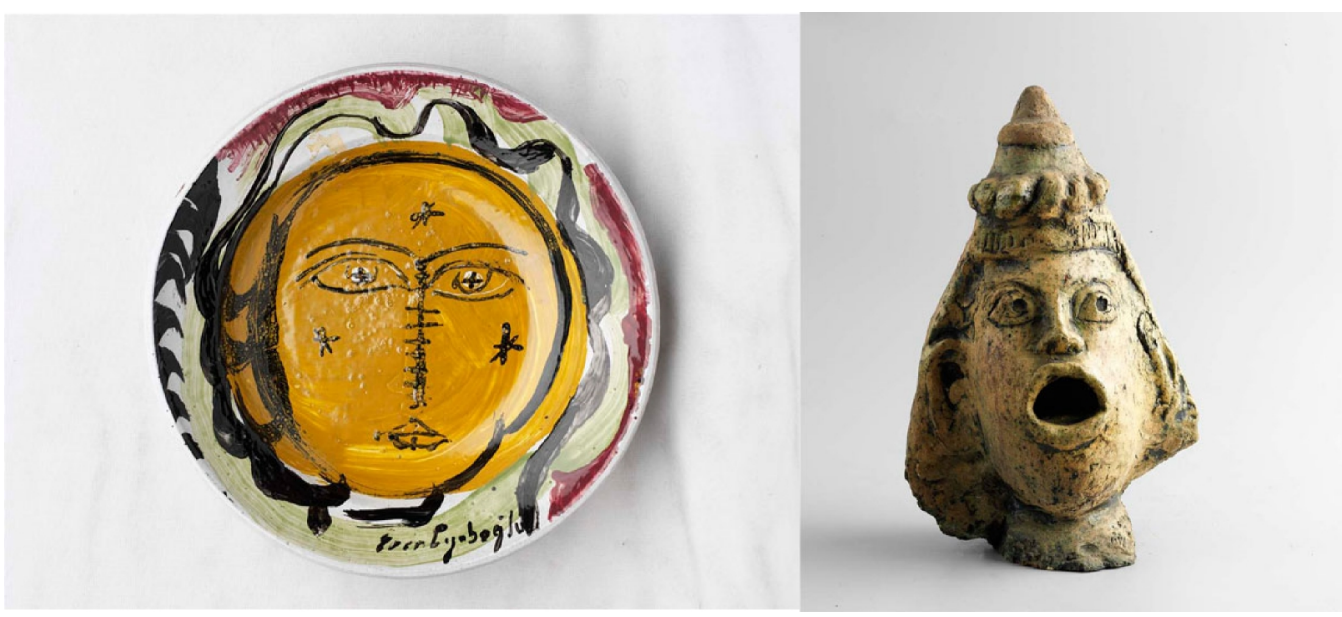

Görsel 13. Eren Eyüboğlu, Sırlı Seramik Tabak Görsel 14. Eren Eyüboğlu, Seramik Obje

İtalyan sanatçı Barnaba Fornasetti, dünyanın en yenilikçi ve tanınmış tasarımcılarından Piero Fornasetti'nin oğludur. Sanatçı babasından aldığı mirası eserlerine aktarmıştır. Farklı kreasyonları ile özgün çalışmaları olan İtalyan sanatçı babasından çocukluğunda aldığı ilhamı ve hatıralarından getirdiği imgeleri eserlerine aktarmıştır (Boniatti, 2018, s. 35). Sanatçı anılarından ilham almış ve onları renklerle ironi dolu bir rüya dünyasına çevirmiştir. Yapıtları büyüleyici bir görsel kimlik geliştirmiştir. Fornasetti'nin 'Tema ve varyasyonları' yıllar içinde yüzlerce dönüşüm ve değişiklik geçirerek ironi ve yeni hayallerin yeni yorumları olmuştur. Sanatçı sonsuz hayal gücünü Lina Cavalieri'nin melankolik gözlerine ve dolgun dudaklarına doğru odaklamış ve yüzü çeşitli gerçeküstü senaryolarda ve durumlarda çerçeveleyecek şekilde uyarlamıştır. Fornasetti eserlerinde, Chaplin, bıyık, gözlük, kayak maskesi, taç ve dil takısı, bir kum saati, kelebek, sıcak hava balonu, plak çalar ve kalıp peynir şeklinde imgeleri kullanmıştır.
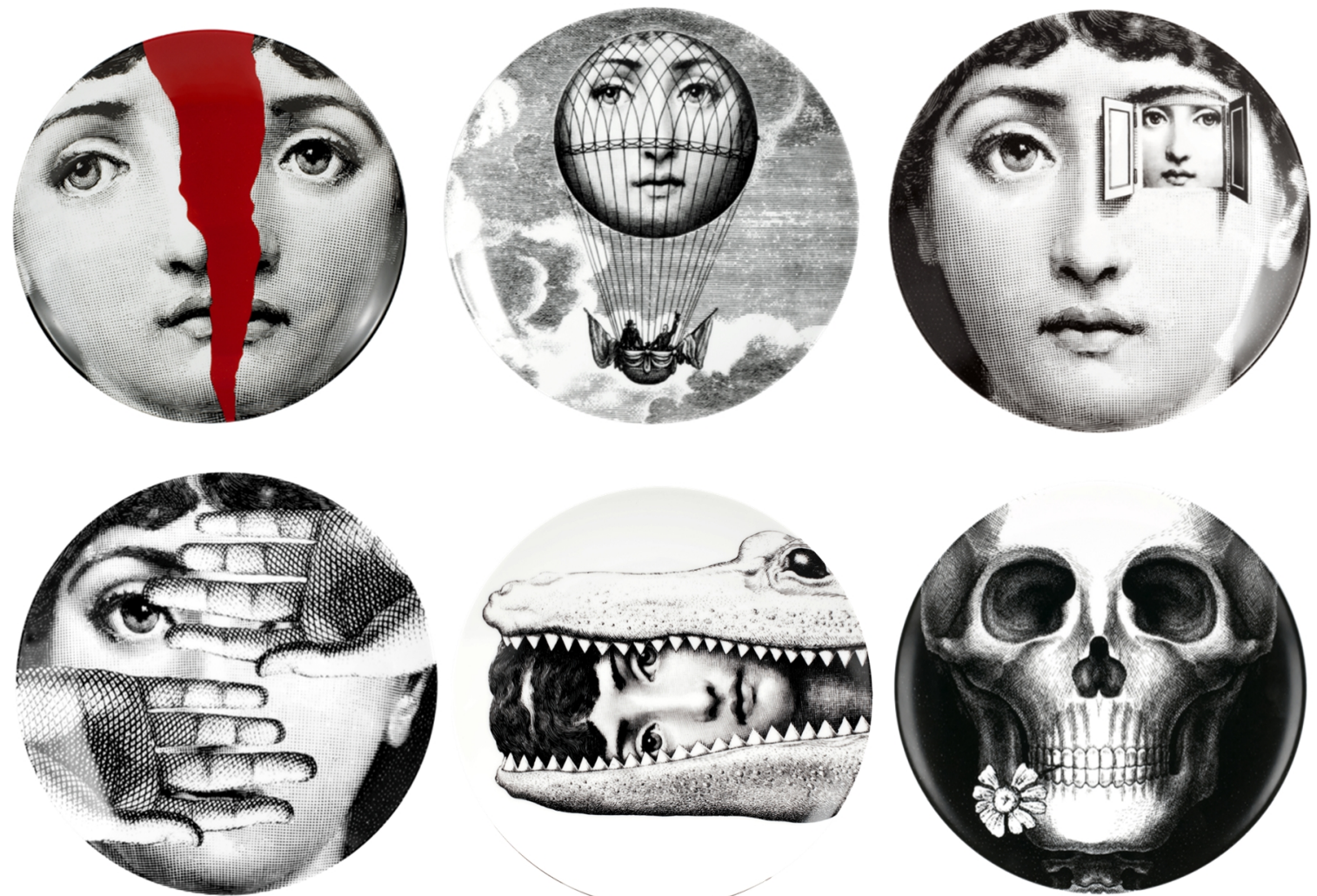

Görsel 15. Piero Fornasetti, Lina Cavalieri, Tema ve Varyasyonları, Porselen, 1955

Güney Koreli sanatçı Lee Haejin'in eserlerinde bitmiş bir şekli ayrıştırma ve sonra parçaları farklı bir sunumda yeniden birleştirme yoluna gitmektedir. Sürecin yeniden inşası ve yapılan yeni oluşumlar, bazen şeritlerin veya çeşitli nesnelerin ya da deforme olmuş yüzlerin ritmik bileşimi, sanatçının araştırmalarının bir sonucu olarak karşımıza çıkmaktadır. Haejin için iyi bir şeklide ayrılmış parçalar onda özgürlük hissi uyandırmaktadır. Beklenen formdan arınmış olması, parçalar arasındaki farklılıkları ve aynı zamanda birlikteliklerini hatırlama motivasyonu 
vermektedir. Sanatçı eserlerinde doğru dokulara ve renklere ulaşmak için tasarladığı kompozisyonu yeniden inşa eder; her adımda ve süreçte belirli miktarda zorluk ve risk alır. Lee Haejin parçalayarak yeniden oluşturduğu eserlerinde yüz formunu kullanmıştır.

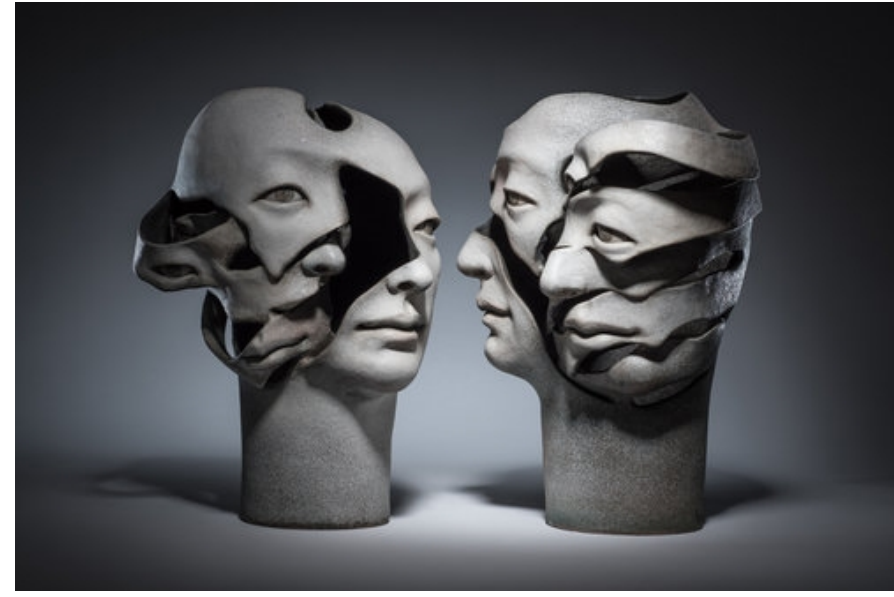

Görsel 16. Lee Haejin, Stoneware çamur, renkli astar, Oksitli pişirim, 2016

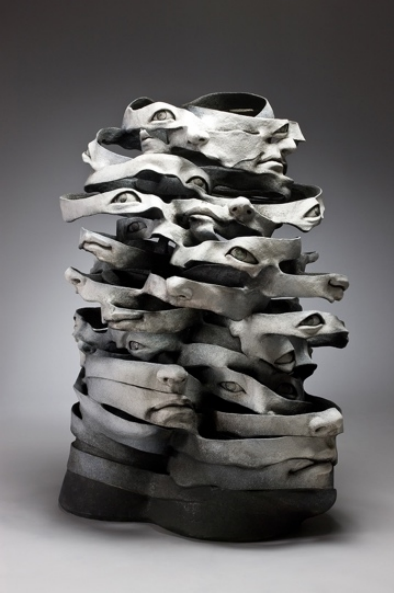

Görsel 17. Lee Haejin, Görüntü ve duygu anıları, 2012

Jessriva Cooper eserlerinde, enstalasyon tabanlı sanat eseri yaratmak için renkleri, çizimleri ve çamuru birleştirmektedir. Yidiş folklorunda Dybbuk'un temel mitlerini incelemekte ve bu geleneksel öyküleri bir kadın merceğiyle yeniden yorumlamaktadır. Cooper, evlerde yaşamın vahşi hale gelişini, nesiller önce ekilen sarmaşık ve ağaçların arkasında yok olmaya yüz tutmuş şehirlerde yaşanan ekonomik ve çevresel krizleri araştırmıștır. Bitki yaşamına olan ilgisi ile insan vücudunu ele geçiren kötü niyetli bir Dybbuk ruhu arasında doğrudan bir paralellik görmektedir. Sanatçı eserlerinde, dünyadaki bitkileri insan yüzlerinde filizlendirmektedir. Cooper'ın eserlerinde renk ve form sessiz bahçelerden patlar gibi görünür ve düzenli mekanlara kaos getirdiği hissi verir. Eserlerinde doğayı yapıtların üzerinde kullanarak geçmiş durumları yıkıp, doğaüstü bir dönüşüm yaratma yoluna gitmiştir.

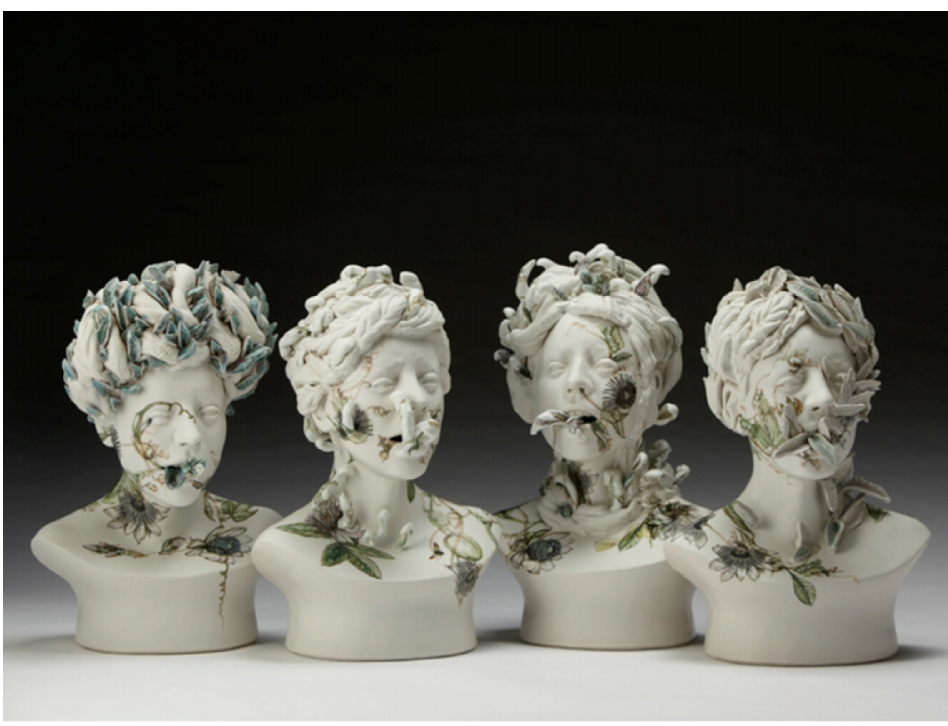

Görsel 18. Jessriva Cooper, Viral Serisi, Sırlı seramik, Çıkartma, 2013

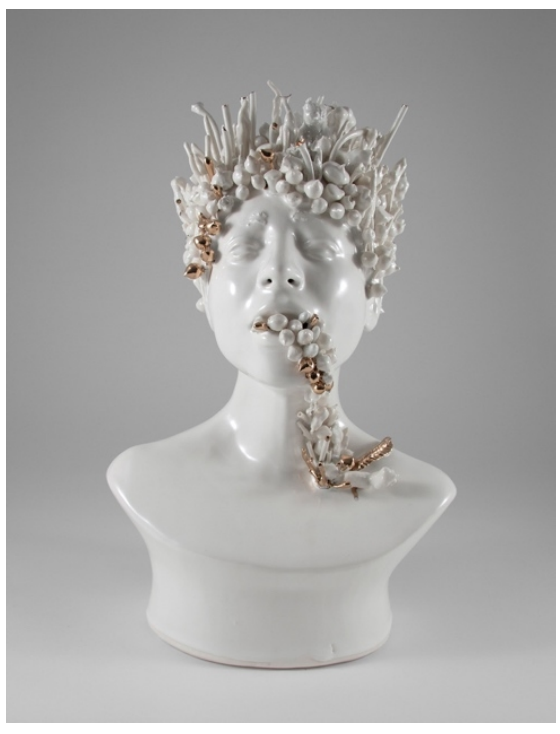

Görsel 19. Jessriva Cooper, Viral Serisi III,

Beyaz ve altın sırlı seramik, 2015

Mehmet Kutlu, kendine özgü araştırmaları, deneyimlerini ve seramik yüzey uygulamalarını resimsel bir anlatım arayışı ile serigrafi tekniği kullanarak seramik alanında çalışmalar üretmektedir. Kutlu tartışmalı konular, çocukluk hayalleri ve heyecan verici olaylardan ilham almaktadır. Sanatçı kendi atölyesinde, araştırmaya ve farklı teknikler üretme süreci içerisinde seramik formlar üzerinde, renklerin ve desenlerin çeşitli alternatiflerinin arayışı içerisine girmiştir. Kutlu ünlülerin portrelerinden oluşan 'Hikâyeler Serisi' duvar panosu yapmıştır. Serigrafi baskı tekniğini porselen üzerinde kullanan sanatçı, yine aynı teknik ve renk arayışları içerisinde çeşitli seramik formlar üzerinde yüz imgeleri kullanmıştır. 


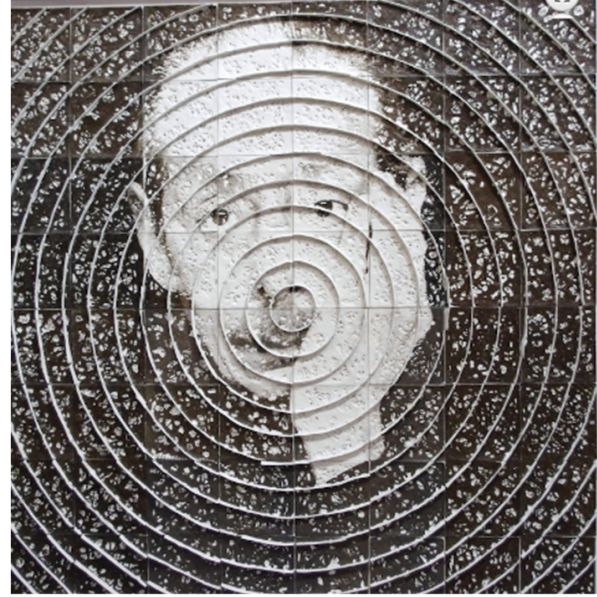

Görsel 20. Mehmet Kutlu, Genco Erkal, Hikâyeler Serisi, Porselen Üzerine Serigrafi Baskı Tekniği

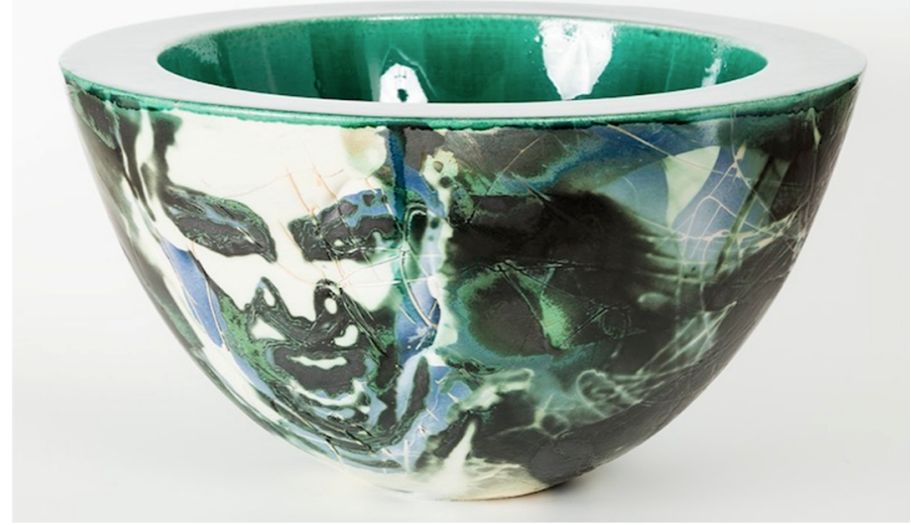

Görsel 21. Mehmet Kutlu, Çı̆̆lık, Porselen, beyaz ve renkli çamur, çift cidarlı kase

Çinli sanatçı Johnson Tsang, eserlerinde, gerçekçiliğin sınırlarını gerçeküstü yollarla anlatmaktadır. Tsang büzülmüş, gerilmiş veya açılan yüzleri sergilemektedir. Sanatçı, eserlerinde el hareketleri, dalgalar, su gibi çeşitli metaforik anlatımlar kullanmaktadır. Tsang, deformasyona uğramış ve aynı zamanda hayret uyandırıcı ifadeleri, abartılı ve gerçeküstü bir yorumla porselen yüzleri üzerinde uygulamıştır. Bedensiz yüzleri ele alarak, dalgaları, elleri, açılmış kafaları ve bir takım imgesel unsurları kullanarak porselen yüzler üretmektedir (Tanrıverdi ve Korkmaz, 2019, s. 661-667).

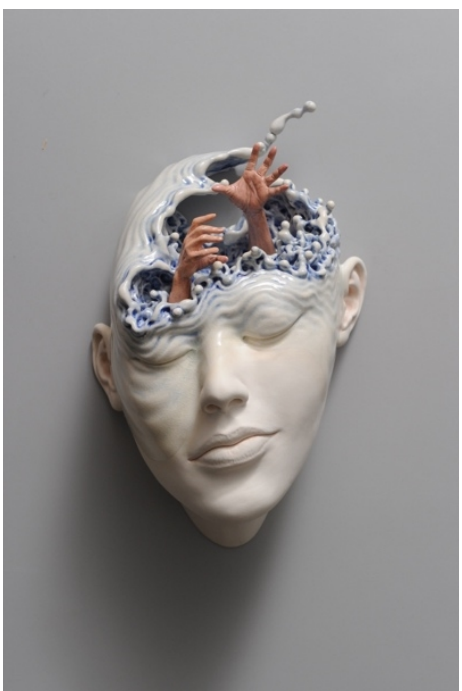

Görsel 22. John Sontsang, Berrak rüyalar II, Aşka düşmek, Porselen, 2016

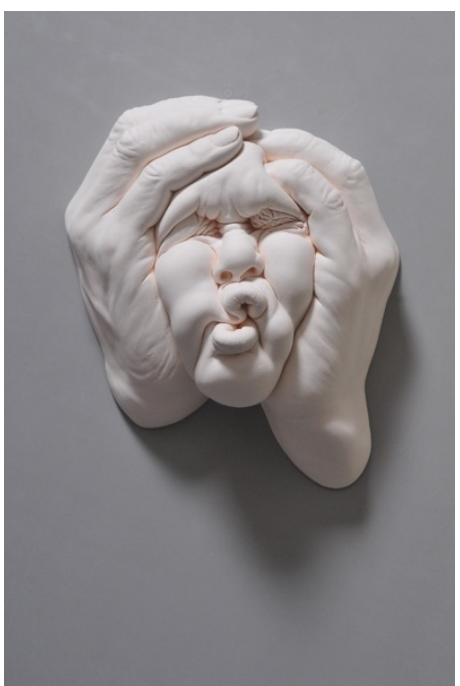

Görsel 23. John Sontsang, Berrak rüyalar II, Yapım aşaması Porselen, 2016

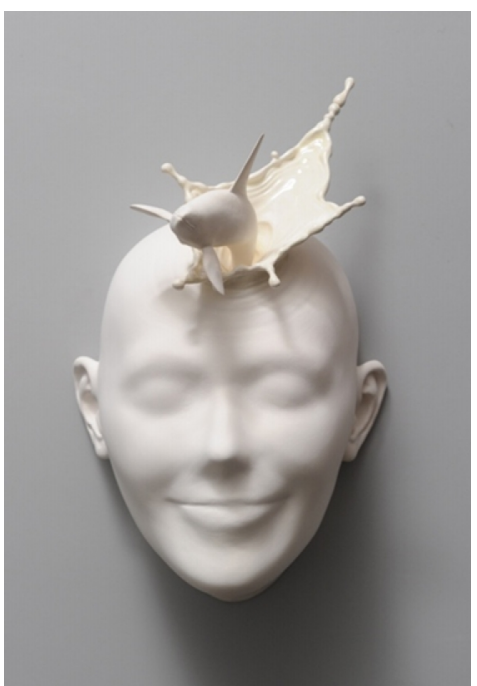

Görsel 24. John Sontsang, Berrak rüyalar II, Sadece dinle Porselen, 2016

Amerikalı sanatçı Peter Lenzo, yaşadığı bölgenin güneyine özgü çömlek geleneğini yüz sürahileri yaparak sürdürmektedir. Peter bazı fonksiyonel ve "işlevsel" olmayan ahşap ve seramik parçaları birleştirerek kendi eserlerini üretmektedir. Geçmişi hatırlayabilir ya da gelecek hakkında hayal kurabiliriz; ama sahip olduğumuz tek şey "şimdi" dir. Peter Lenzo da tam da anı yaşamaktadır. Sanatçı, 1977'de geçirdiği talihsiz bir bisiklet kazası nedeniyle bugün epilepsi nöbetleri geçirmektedir. Lorenzo eserlerinde kendi acısını ifade etme yoluna gider. Eserlerde bazen daha deforme olmuş yüz şeklindeki testileri "bu kötü günlerimden biriydi" nin işareti olarak ifadelendirmektedir. 


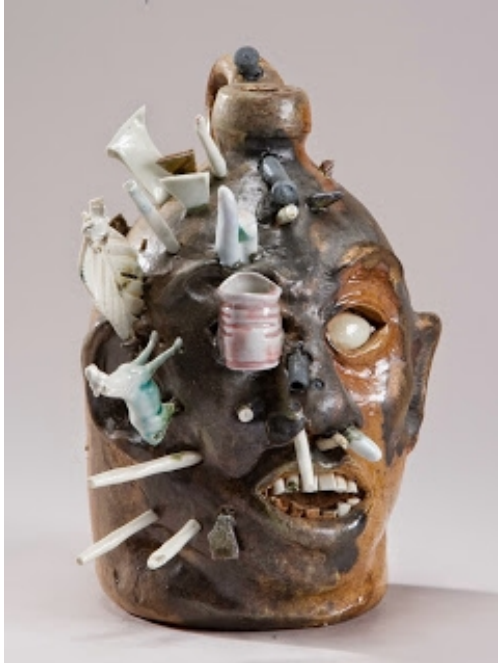

Görsel 25. Peter Lenzo,

Göze Pembe Vuruş, 2000

stoneware ve porselen, astarlar, sirlar ve buluntu objeler

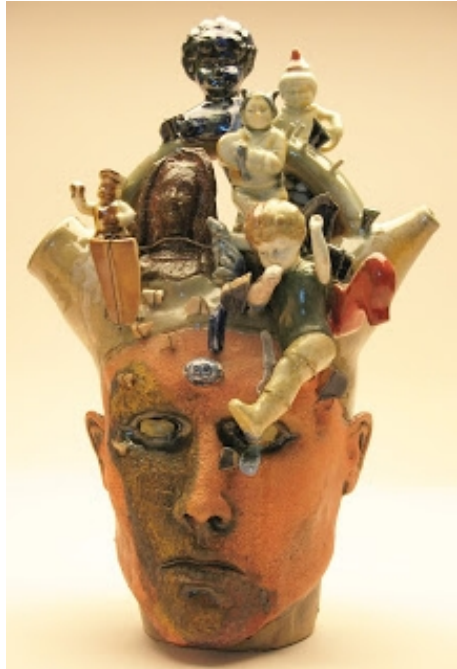

Görsel 26. Peter Lenzo,

Kirmızı Ayakkab1, 2015,

stoneware ve porselen, astarlar, sirlar ve buluntu objeler

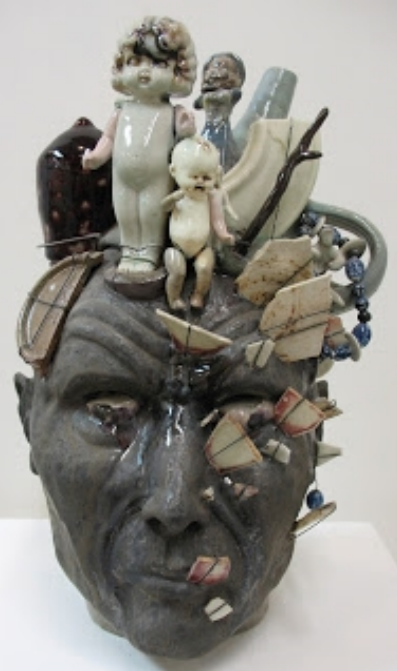

Görsel 27. Peter Lenzo,

Sadece Beynim Olsayd1, 2015, stoneware ve porselen, astarlar, sirlar ve buluntu objeler

Tuba Korkmaz eserlerinde kendi kimliğinin getirdiklerini belleği ile şekillendirdiği haliyle kullanmaktadır. Korkmaz 'İstedim ki bilineyim’ serisinde, kadın kimliğini, anne kimliğini ve daha birçok farklı kimlikleri dışarıda bırakarak sadece kendi duygu ve yaşanmışlıklarının içerildiği bir seri üretmiş ve kendi hikayesini seramik yüzeylere aktarmıştır. Sanatçı, yüz felci nedeni ile asimetrik bir yapıya sahip olan bir portreyi, tam ortadan ikiye bölmüş ve yan yana gelen karolarla görüntünün tamamlanmasını sağlamaya çalışmıştır. Bu yolla asimetrik görünen yüzü örtbas edilmiş ve aynı zamanda dikkati asimetriye çekmiştir. Sanatçı bu yolla sonsuza kadar tekrarı seramik karolara aktarmıştır. Korkmaz, bilgisayar ortamında hazırlanmış olan dijital görüntüleri, inkjet teknolojisi ile yüzeye aktarmıştır.

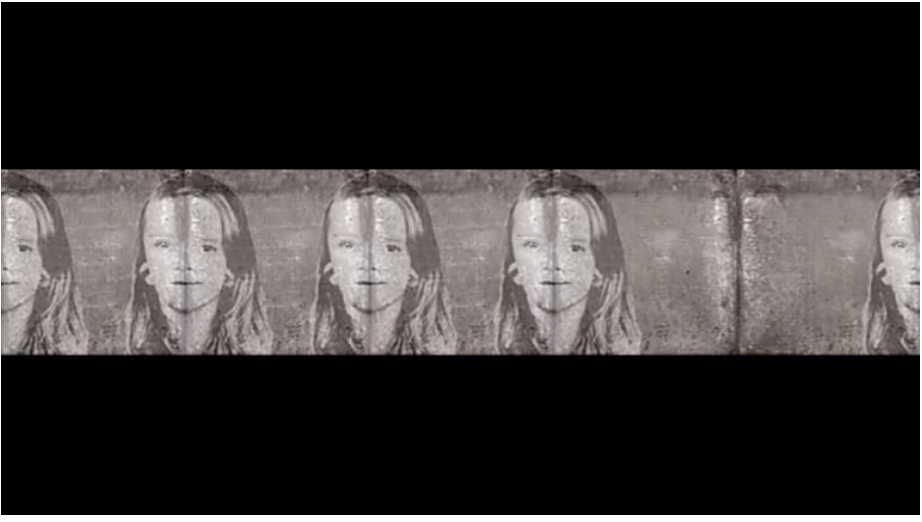

Görsel 28. Tuba Korkmaz, İstedim ki Bilineyim Serisi, Sonsuz Tekrar, 2015

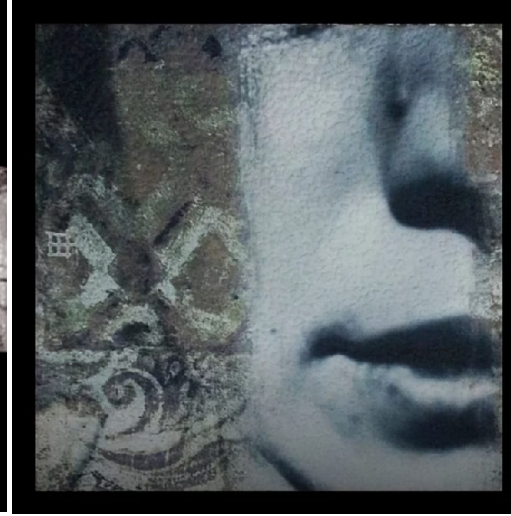

Görsel 29. Tuba Korkmaz, İstedim ki Bilineyim Serisi, Otoportre, 2015

\section{Sonuc}

İletişime geçerken kullandığımız yüz ifadeleri duyguların aktarımında çok önemli bir yere sahiptir. Beden farklı şekilde davransa bile gözler duygunun tam karşılığını aktarmaktadır. Acıyı, mutluluğu, korkuyu, endişeyi içsel olarak yaşayıp farkına bile varamadığımız bazı duyguları yüz aracılığıyla net bir şekilde aktarabiliriz. Yaşam boyunca edindiğimiz farklı kimlikler, kişiliğimizi zenginleştirebildiği gibi farkında olmadığımız yüklere de dönüşebilmektedir. Bunlar da aslında bizden ayrı olan şeyler değil, bizi biz yapan bütünün bir parçasıdır.

Seramik tarih boyunca kültürel aktarımın bir aracı olmuş, farklı toplumlarda, farklı tekniklerle birlikte bellek oluşturmaya devam etmiştir. Seramik ilk çağlardan bu yana günlük yaşam gereçlerinden dini törenlerde kullanılan malzemelere kadar her alanda yer almıştır. Yüzün, ifadenin aktarımındaki gücü, seramik sanatçıları tarafından önemsenmiş, eserlerinde imgesel olarak kullanılmıştır. Eski çağlarda ölülerin ruhlarının tekrar döneceği inancıyla cesetlere yüz maskesi yapılması, yüz imgesinin ilk kullanıldığı yer olmuştur. Sanatçılar, farklı tekniklerle birlikte bu güçlü aktarım imgesini eserlerinde ifadeyi kuvvetlendirmek adına kullanmışlardır. Günümüzde halen birçok sanatçının eserlerinde yüz imgesinin kullanıldığı görülmektedir. İletişimin en etkin şekilde ifade bulduğu yüz, 
sanat eserleriyle birleştiğinde güçlü bir anlatıma aracılık etmiştir. Bir ifade aracı olan yüz imgesinin gelecek nesiller tarafından da kullanılmaya devam edeceği düşünülmektedir.

\section{Kaynakça}

Bayrakdar, S., \& Akgün, D., \& Yücedağ, İ. (2016). Yüz ifadelerinin otomatik analizi üzerine bir literatür çalışması. SAÜ Fen Bil Dergisi, 20(2), 383-398. Erişim adresi: http://www.saujs.sakarya.edu.tr/tr/download/articlefile/227629

Boniatti, K. (2018). Barnaba Fornasetti. Casa Living, Ekim.

Civelek, A. (2007). Roma cenaze törenleri ve gömme gelenekleri. Arkeoloji ve Sanat Dergisi, 124, 71-80.

Donnan, C. B. (1979). Moche art of Peru: Pre-Columbian symbolic communication. Los Angeles: Museum of Culture History.

Ergil, D. (1994). Toplum ve insan. Turhan Kitabevi, Ankara.

Güneş, T. \& Polat, E. (2009). Yüz ifade analizinde öznitelik seçimi ve çoklu svm siniflandiricilarina etkisi. Gazi Üniversitesi Mühendislik Mimarlık Fakültesi Dergisi, 24(1), 7-14. Erişim adresi: https://dergipark.org.tr/tr/ download/article-file/75454

Hirst, C. (2017). The Jericho skull, creating an ancestor. Papers from the Institute of Archaeology, British Museum Exhibition Review, 27(1), 1-4.

İnan, H. B. (2018). Seramik form ve yüzeylerde resimsel anlatımlar ve imgeler (Yüksek Lisans Tezi). YÖK Tez veri tabanından erişildi. (Tez No. 531113)

Metin, A., \& Doğan, T. (2019). Psikolojik danışman adaylarının, yüz ifadelerindeki duyguları tanıma becerileri. Hacettepe Üniversitesi Eğitim Fakültesi Dergisi, 1-26. doi: https://doi.org/10.16986/HUJE.2019053944

Rowe, M. (2015). Museum of the native American history: A pictorial journey. Rapid City: Museum of The Native American History Press.

Sayın, Z. (1999). Mithat Şen ve beden yazısı. İstanbul: Kaknüs Yayınları.

Sayın, Z. (2003). Imgenin pornografisi. İstanbul: Metis Yayınları.

Şimşek, S. (2002). Günümüzün kimlik sorunu ve bu sorunun yaşandiği temel çatışma eksenleri. Uluda $\breve{g}$ Üniversitesi Fen Edebiyat Fakültesi Sosyal Bilimler Dergisi, 3(3), 29-39. Erişim adresi: https://dergipark.org.tr/tr/download/article-file/214786

Tanrıverdi, Y., \& Korkmaz, T. (2019). Farkındalı̆̆ın sanatsal dışavurumu. III. Uluslararası Farkındalık Konferansında sunulan bildiri, ÇOMÜ Troia Kültür Merkezi, Çanakkale.

\section{Görsel Kaynakçası}

Görsel 1. Jericho Kafatas1, British Museum, Hirst, C. (2017). The Jericho skull, creating an ancestor. Papers from the Institute of Archaeology, British Museum Exhibition Review, 27(1), 1-4.

Görsel 2. Roma-Mısır Çömlekçilik Maskesi, Erişim adresi: https://www.alexanderancientart.com/681.php

Görsel 3. Roma Cumhuriyetinden kalma çocuk maskesi, Sayın, Z. (2003). Imgenin pornografisi. İstanbul: Metis Yayınları.

Görsel 4. Tashtyk Kültür, bir adamın kafasına yapılmış ölüm maskesi, Erişim adresi: https://www.hermitagemuseum.org

Görsel 5. Antik Peru Moche uygarlığından bir seramik kaplar, Donnan, C. B. (2004). Moche portraits from ancient Peru. USA: Texas University Press.

Görsel 6. Kafa Şeklinde Ritüel Seramik kap, M.S. 600-900, Geç Klasik Maya Yucatan, Meksika, Erişim adresi: https://www.artic.edu/

Görsel 7. Missipi kafa kapları, Rowe, M. (2015). Museum of the native American history: A pictorial journey. Rapid City: Museum of The Native American History Press.

Görsel 8. Missipi kafa kapları, Erişim adresi: https://www.instagram.com/archaeologyink/

Görsel 9. Pablo Picasso, Boyanmiş ve Sirlanmiş Toprak Tabak (1947). Erişim adresi: https://blog.peramuzesi.org.tr/sergiler/picassonun-seramikleri/ 
Görsel 10. Pablo Picasso, Siyahla Boyanmış Kırmızı Seramik Vazo, (1963). Erişim adresi: https://www.louisiana.dk/en/event/klub-udstillings\%C3\%A5bning-picasso-keramik-3112018

Görsel 11. Bedrim Rahmi Eyüboğlu, Seramik Heykel, Erişim adresi: http://www.rahmieyuboglu.com/bedri rahmieyuboglu/sanatci-kisiligi/seramik-ustasi

Görsel 12. Bedrim Rahmi Eyüboğlu, Seramik Heykel, Erişim adresi: rahmi-eyuboglu/sanatci-kisiligi/seramik ustasi

Görsel 13. Eren Eyüboğlu, Seramik Sırlı Tabak, Erişim adresi: http://www.rahmieyuboglu.com/eren-eyuboglu/ sanatci-kisiligi/seramik-ustasi

Görsel 14. Eren Eyüboğlu, Seramik Obje, Erişim adresi: http://www.rahmieyuboglu.com/eren-eyuboglu/sanatcikisiligi/seramik-ustasi

Görsel 15. Piero Fornasetti, (1955), Lina Cavalieri, Tema ve Varyasyonları, Porselen, Erişim adresi: http://www.fornasetti.com/collection/ceramic-category/accessories

Görsel 16. Lee Haejin, Stoneware çamur, 2016, Erişim adresi: http://haejinlee- ceramics.com/2017/9/11/memoirsof-image-and- emotions-2

Görsel 17. Lee Haejin, Görüntü ve duygu anıları, 2012, Erişim adresi: http://haejinleeceramics.com/2017/9/11/memoirs-of-image-and- emotions-2

Görsel 18. Jessriva Cooper,(2013), Viral Serisi, Sırlı seramik, Erişim adresi: http://www.jessrivacooper.com/

Görsel 19. Jessriva Cooper, (2015), Viral Serisi III, Beyaz ve altın sırlı seramik, Erişim adresi: http://www.jessrivacooper.com/

Görsel 20. Mehmet Kutlu, Genco Erkal, Hikâyeler Serisi, Porselen Üzerine Serigrafi Baskı Tekniği, Erişim adresi: http://www.mehmetkutlu.com/works/

Görsel 21. Mehmet Kutlu, Çığlık, Porselen, beyaz ve renkli çamur, çift cidarlı kase, Erişim adresi: http://www.mehmetkutlu.com/works/

Görsel 22. John Sontsang, Berrak rüyalar II, Aşka düşmek, Porselen, 2016, Erişim adresi: https://johnsontsang.wordpress.com/

Görsel 23. John Sontsang, Berrak rüyalar II, Yapım aşaması, Porselen, 2016, Erişim adresi: https://johnsontsang.wordpress.com/

Görsel 24. John Sontsang, Berrak rüyalar II, Sadece dinle, Porselen, 2016, Erişim adresi: https://johnsontsang.wordpress.com/

Görsel 25. Peter Lenzo, Göze Pembe Vuruş, (2000), Erişim adresi: http://peterlenzo.blogspot.com/2012/08/ ceramic-heads-and-face-jugs.html

Görsel 26. Peter Lenzo, Kırmızı Ayakkab1, (2015), Erişim adresi: http://peterlenzo.blogspot.com/2012/08/ ceramic-heads-and-face-jugs.html

Görsel 27. Peter Lenzo, Sadece Beynim Olsayd1, (2015), Erişim adresi: http://peterlenzo.blogspot.com/2012/08/ ceramic-heads-and-face-jugs.html

Görsel 28. Tuba Korkmaz, İstedim ki Bilineyim Serisi, 2015, Sonsuz Tekrar, 2015, Sanatçının arşivinden

Görsel 29. Tuba Korkmaz, İstedim ki Bilineyim Serisi, 2015, Otoportre, Sanatçının arşivinden 